\title{
Analysis Of The Profitability of Investment In Renewable Energy Sources On The Example of A Semi-Detached House
}

\author{
Elżbieta Radziszewska-Zielina ${ }^{1 a}$ Renata Rumin² \\ ${ }^{1}$ Institute of Management in Construction and Transport, Cracow University of Technology, Poland \\ ${ }^{2}$ Cracow University of Technology, Poland
}

\begin{abstract}
The paper presents an analysis of the profitability of investment in a selection of systems based on renewable energy sources on the example of a semi-detached house with a floor area of nearly $150 \mathrm{~m}^{2}$. The analysis was conducted in three variants:1) the application of a biomass boiler, solar collectors and photovoltaic panels; 2) a heat pump, solar collectors and photovoltaic panels; 3 ) a heat pump, solar collectors and a wind turbine. Next, the proposed solutions were compared with a traditional heating system featuring a gas-powered boiler and obtaining electricity through the power distribution grid. The investment and operational costs were calculated after the selection of the appropriate equipment. The example under analysis indicates that variant 3 entailed the highest investment costs (the purchase and fitting of a heat pump as well as the drilling required to install underground pumps). Traditional technical solutions were proven to produce the highest costs. The investment profitability analysis was conducted using both the simple and discounted methods of evaluating profitability. It was established that variant 3 yielded the shortest discounted payback period - less than 13 years. It is estimated that the investment will reach the break-even point after this time. As a summary, it must be noted that the profitability of a given investment depends on the adopted technical solutions. Due to high initials costs, investors often lack interest in the purchase and installation of renewable energy generation systems; however, the contribution of the investors can be lowered with the use of subsidies and price reductions regarding the installation of renewable energy generation systems. We can observe a decrease in the price of the most popular and efficient renewable energy systems.
\end{abstract}

\section{Introduction}

Only $10 \%$ of Poland's energy is generated using renewable energy sources. The production of energy is still based on fossil fuels, mostly coal and lignite. This leads to a gradual increase in air pollution, something that is particularly felt in urbanised areas. The large emission of dust particles, sulphur and nitrous oxide negatively impacts the health of humans and leads to the degradation of buildings and architectural elements. The use of fossil fuels is also economically tied to the problem of finite resources and the rising difficulty in accessing their deposits. It is estimated that the global crude oil and natural gas deposits are going to be depleted in around 50 years, while those of coal in around 150 years. This directly impacts the costs of energy. The factors presented above, along with an increase in social awareness, are leading to a heightened interest in alternative energy sources $[1,2,3,6]$.

Non-conventional energy sources are used in many fields of everyday life. One can observe an increase in interest in energy efficient building construction, as well as in systems that utilise alternative energy sources for use in residential architecture. Public opinion polls indicate

\footnotetext{
${ }^{\mathrm{a}}$ Corresponding author: eradzisz@izwbit.pk.edu.pl
}

that $45 \%$ of citizens prefer the use of renewable energy, mostly in the form of solar or wind power. It is estimated that the number of households that have invested in microinstallations is going to reach around 2500 thousand [4, 5]. Thanks to the rising popularity of alternative energy systems, we can observe a rise in the demand for modern technologies, which is going to result in the lowering of the costs of installing them in the future. Profitability is one of the most important factors in construction projects, with $50 \%$ of respondents claiming that the payback period should not exceed 7 years $[4,5]$. A large influence on the aforementioned rise in popularity is attributed to changes in legislation that force the adoption of different approaches to designing buildings and the use of alternative energy sources. Pollution emission and energy demand standards are becoming more and more strict, like the ones regarding heat transfer coefficient values $[7,8]$.

The paper illustrates an analysis of the profitability of a selection of systems that are based on renewable energy sources on the example of a semi-detached single family house. 


\section{Description of the analysed building}

The analysis was conducted for an existing semi-detached single family house, fit for use by two fourperson families. The design of the house was developed in 2010. The building is composed of two residential sections, with each of them having a net floor area of $147,42 \mathrm{~m}^{2}$. The total volume of the structure amounts to $1141,40 \mathrm{~m}^{3}$. The building is symmetrical in terms of both form and function. It is located in the town of Nowy Sącz in the Małopolskie Voivodship. The house is located in the III climate zone (PN-EN 12831). The building has been determined to be partially covered. It is a single storey house with a usable attic, covered by a gabled roof with a 30 degree incline. The house faces the south. The foundations are composed of both continuous and point footing with a height of $40 \mathrm{~cm}$ and a width of 60 to $70 \mathrm{~cm}$. They are placed on a $10 \mathrm{~cm}$ layer of lean concrete. The building is insulated against water by the means of a waterproofing compound. The floor slabs are placed on a $15 \mathrm{~cm}$ thick layer of sand, with the slabs themselves being $15 \mathrm{~cm}$ thick. The slab on grade is waterproofed by the means of two layers of heated bitumen membranes connected by the means of an anionic asphalt emulsion, with thermal insulation provided by $10 \mathrm{~cm}$ thick styrofoam plates. The walls of the foundations are made of concrete and are $25 \mathrm{~cm}$ thick. The part of the foundations located below ground is waterproofed by a layer of bituminous coating with thermal insulation provided by an $8 \mathrm{~cm}$ thick layer of styrofoam that is suitable for use underground. The house has two-layer external masonry walls. The loadbearing layer is composed of $25 \mathrm{~cm}$ thick, traditionally bound ceramic blocks. The external layer of thermal insulation is composed of $12 \mathrm{~cm}$ thick styrofoam plates. The total thickness of its external walls is equal to $37 \mathrm{~cm}$. The heat transfer coefficient for these walls equals $\mathrm{U}=0,29 \mathrm{~W} / \mathrm{m}^{2} \mathrm{~K}$. There is a wooden entry door and a garage door in the northern facade, possessing a heat transfer coefficient of $\mathrm{U}=1,5 \mathrm{~W} / \mathrm{m}^{2} \mathrm{~K}$, while the heat transfer coefficient of the windows equals $\mathrm{U}=1,7 \mathrm{~W} / \mathrm{m}^{2} \mathrm{~K}$. The building in question is covered by a gabled timber purlin and collar-beam roof. The roof cladding is composed of concrete tiles. The roof is thermally insulated using mineral wool with a thickness of $20 \mathrm{~cm}$. The heat transfer coefficient for the roof is equal to $0,18 \mathrm{~W} / \mathrm{m}^{2} \mathrm{~K}$.

\section{The analysed variants}

Variant I: natural gas-powered boiler, electricity drawn from the power grid.

The first variant to be analysed is features the use of a natural gas-powered boiler that is used for heating and providing warm water, with electrical power being drawn from the power grid. This variant is going to be used for comparison.

The building already contains a natural gas-powered condensing boiler with the appropriate infrastructure, so it does not qualify as an investment cost. The key element of this variant are the operation costs.
These include the costs associated with the transfer of gas fuel, drawing electricity from the power grid and the maintenance costs of the boiler. According to art. 62 of the Construction Law Act [7], the owner of a building is to perform an assessment of the technical condition of its gas installation. Appropriate calculations have been made, yielding the yearly cost of heating the building and its water at 3993,47 PLN, with the cost of electricity amounting to 1891,26 PLN, which sums up to a cost of 5942,86 PLN

Total operational cost: 5 942,86 PLN.

Variant II: biomass-powered boiler, solar thermal collectors and photovoltaic panels.

The biomass-powered boiler is going to heat the building and provide warm water, with the solar collectors providing the ability to reheat it, while photovoltaic panels are going to be used for energy generation. The Polish market is currently replete with biomass-powered boilers. The most popular ones include those that can use wood or pellets for fuel. The analysis was performed for a pellet-fuelled boiler and a flat set of solar power collectors. Such a set is suitable for a building with 4 inhabitants.

Another piece of equipment utilising the energy of the sun are photovoltaic panels. The analysed case features a photovoltaic power generator with a capacity for generating $3,0 \mathrm{~kW}$. The existing heating system of the building is assumed to be in good condition, without the need to replace it or any of its parts.

Conditions set for the calculations: $50 \%$ of the energy generated by the photovoltaic panels is going to be used by the inhabitants, while the other $50 \%$ is going to be sold to the power company. The estimated production of power by photovoltaic panels amounts to $3000 \mathrm{kWh}$.

Total investment costs: 46 669,46 PLN

Total yearly operational costs: $\mathbf{2}$ 725,74 PLN

The authors performed an analysis of the profitability of using a biomass-powered boiler to provide heating to a single family house, solar collectors to provide warm water and photovoltaic panels to produce electricity.

The discounted payback period is the time required for the investment costs to be covered by the benefits generated by the investment, while taking into account the possible changes to the value of money. The shorter the payback period the more profitable the investment.

The simple payback period in this case amounts to 14,5 years, while the discounted payback period is 19,5 years. The investment featuring this configuration is thus unprofitable.

Variant III: heat pump, solar thermal collectors and photovoltaic panels.

The purpose of the heat pump is going to be to provide heating for the building as well as to produce warm water, which is going to be reheated using solar thermal collectors, while photovoltaic panels are going to be used to produce electricity.

The analysis is based on a heat pump with the following parameters: the pump operates within the range of 5,8 do $17,2 \mathrm{~kW}$, has a COP coefficient of 4 , 
and its size equals 1049 × $600 \times 845 \mathrm{~mm}$. It weights 119 $\mathrm{kg}$ and produces $<45 \mathrm{~dB}$ of noise. It can work in unison with an additional source of heat. The analysis estimates that $40 \%$ of the energy needed to provide warm water is going to be obtained from the heat pump.

The operational costs need to be increased to take into account the value of mandatory maintenance.

Total investment costs: 73 059,85 PLN

Total yearly operational costs: 2 144,49 PLN

The simple payback period in this case is 19,2 years, while the discounted payback period (with a discount rate of $3 \%$ ) is 29,7 years. The investment featuring this configuration is thus unprofitable.

Variant IV: heat pump, solar thermal collectors and a wind turbine.

The heat pump is going to be used to provide heating for the building and to produce warm water, while solar thermal collectors are going to be used to reheat it, with the wind turbine used to produce electric power.

The interest in compact wind turbine generators in Poland is continuously rising. For the purposes of this analysis, a turbine with a power generation capacity of 3,0 $\mathrm{kW}$ was used.

The turbine is based on a patented structure that features a five-winged fan with a symmetrical, aerodynamic shape. This shape allows it to produce a maximum power output equal to the full capacity of its rotor even at low wind speeds. The effectiveness of this model can exceed that of three-fanned models by up to $40 \%$.

The investment costs are relatively high, which is why it is important to take into account the operational costs when determining the profitability of the investment.

Total investment costs: 79 854,73 PLN

Total operational costs: +1 752,27 PLN

The simple payback period in this case amounts to 10,4 years, while the discounted payback period (with a discount rate of $3 \%$ ) is 12,7 years. The investment in question has been determined to be profitable using this configuration.

\section{Conclusions derived from the analysis}

The solutions that utilise unconventional energy generation solutions are currently quite expensive when compared against wages, with investment costs considered quite high. However, we can observe a steady decline in the price of equipment that uses alternative energy sources. There currently exist numerous opportunities to obtain appropriate subsidies, which make the overall investment costs of purchasing and installing such equipment lower, leading to an increased popularity of this type of solution. Fig. 1 shows a comparative plot illustrating the investment costs of each of the variants that were analysed.

As we can see from the plot presented above (fig. 1) the cheapest solution appears to be variant II, which

utilises a biomass-powered boiler and photovoltaic panels. The most expensive of the variants is variant IV, utilising a heat pump and a wind turbine. The cost of purchasing and installing a biomass-powered boiler is rather low. The structure of the boiler, which uses heat generated from the burning of pellets, is not complicated. However, it needs to be pointed out that operating it is rather time-consuming. It requires manual operation and is not maintenance-free, in contrast to a heat pump, for instance.

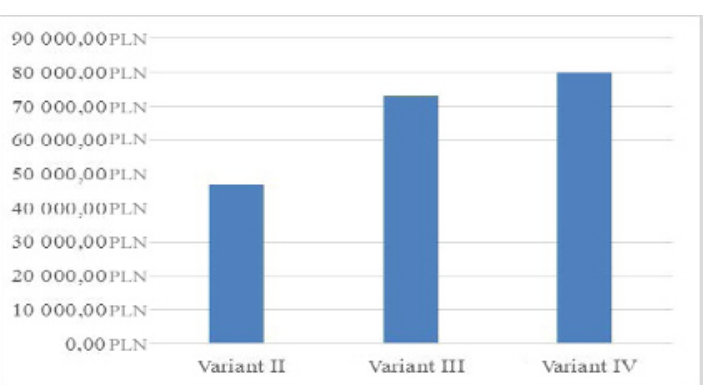

Figure 1. The investment costs for each of the variants

The difference in the amount of investment costs for the variant in which the photovoltaic panels were replaced with a wind turbine is not that large. However, there is a marked increase in the energy that is being produced. Maintenance costs are the most important factor in the comparison between the variants. The analysis presented above features costs that were calculated for a period of one year, which amounted to the purchase of fuel (natural gas, pellets), the purchase and selling of electrical energy (the amount of energy that was used was increased in the case of equipment which made use of renewable energy sources) and the costs of yearly maintenance. Fig. 2 illustrates the operational costs for each variant.

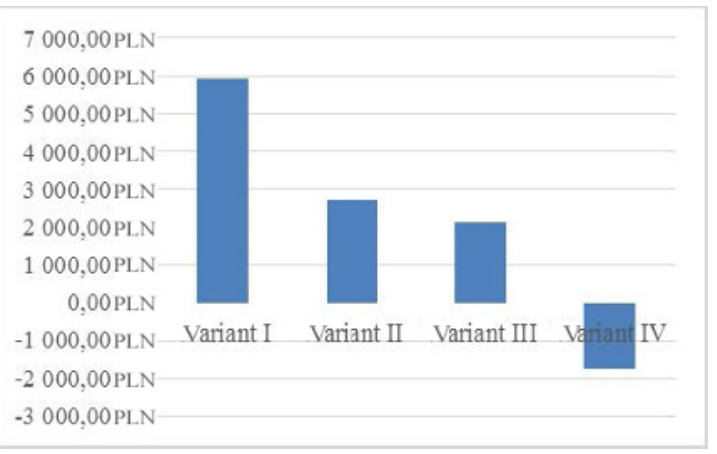

Figure 2. The operational costs for each of the variants

Figure 2 illustrates that the use of natural gas to heat a building and produce warm water is over twice as expensive as using renewable energy sources. The yearly cost of using a boiler consuming natural gas purchased from the gas distribution network amounts to 5 942,86 PLN. The lower yearly operational costs of variant II in comparison to the current equipment installed in the building are based on the fact that the costs of fuel are lower, as well as due to the generation and selling of excess energy back to the power company, in accordance with the Renewable Energy Sources Act. Variant IV, thanks to an increase in the amount of electrical power that it produces thanks to a wind turbine 
rather than photovoltaic panels, allows a homeowner to obtain a profit from this system.

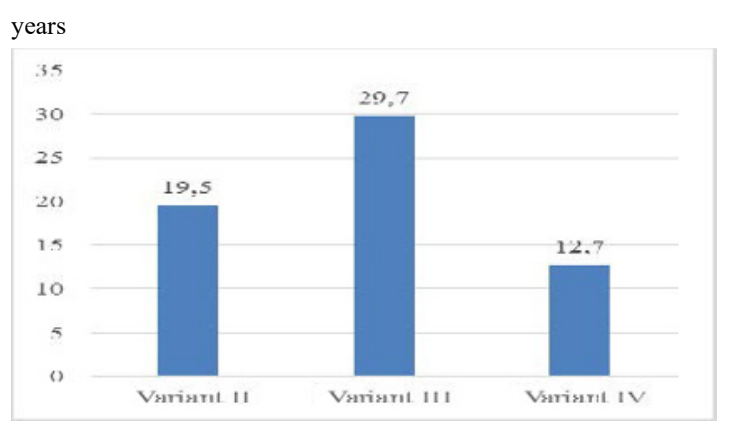

Figure 3. The discounted payback period

The simple payback periods for variants II and IV show that their use can be profitable, as the period for these variants is lower than 15 years. Investing in variant III is unprofitable. The costs of a heat pump are too great for the investment to become profitable in the case of the single family house under analysis.

The discounted payback period (fig. 3) indicates that the most profitable variant is variant IV, as the period is less than 13 years. This is the time it takes for the investment to reach its break-even point. The most profitable investment is variant IV (fig. 4).

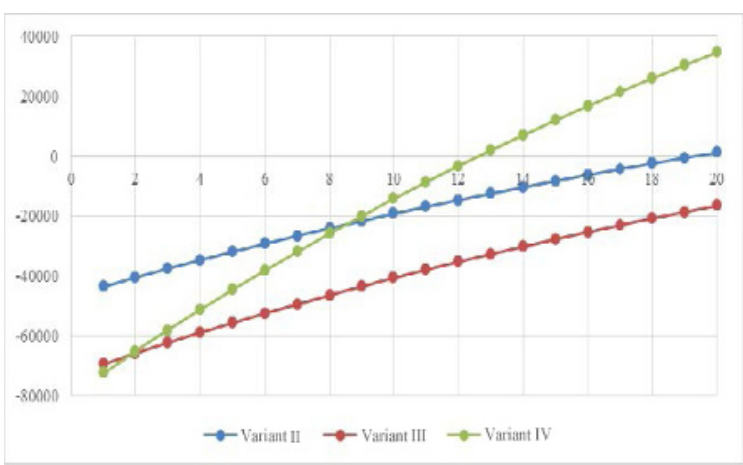

Figure 4. NPV for 20-year period for each of the variants

The investment profitability analysis of investing in renewable energy sources for a single family house has shown that investing in unconventional energy sources can be profitable. However, a potential investor needs to compare the various systems and pick the optimal one for a given structure.

\section{Conclusion}

The analysis of three variants of systems based on renewable energy sources used for heating and producing warm water and comparing them to an existing system in a semi-detached single family house has shown that such equipment can be profitable, provided its choice optimal. Selecting equipment with different parameters from those that the authors have picked for the analysis may produce different results.

Unconventional energy sources in Poland are relatively expensive when wage-wise, with investment costs being comparatively high. However, we can observe a steady decline in price levels of such equipment. There currently exists a possibility of obtaining subsidies that can make the overall investment costs needed to purchase and install such systems much lower, making their use more and more popular. The operational costs of renewable energy systems are much lower than those of traditional systems. Due to the fact that alternative energy systems mostly make use of free energy, there are no fears related to uncertainty related to an unstable market situation regarding the rising prices of fossil fuels. The investment costs of the systems that use fossil fuels are much lower than those of renewable energy sources. However, their operational costs can be considered high. The profitability of an investment depends on the variant under analysis. Investors are often uninterested in the purchase of such systems. However, thanks to numerous subsidies and price reductions that are obtainable for the purposes of installing renewable energy generation systems, the costs to investors can be substantially reduced. We can also observe a reduction in the price of the most popular and the most effective systems making use of renewable energy sources, as well as a marked increase in the demand for such systems.

\section{References}

1. A. Hilarowicz, J. Kozioł (ed.), Odnawialne źródła energii- badania oddziatywań spotecznych, (Politechnika Śląska, Gliwice 2013)

2. F. Krawiec, Odnawialne źródta enegii $w$ świetle globalnego kryzysu energetycznego. Wybrane problemy, (Difin, Warsaw 2010)

3. W. Lewandowski, Proekologiczne odnawialne źródła energii, (WNT, Warsaw 2012)

4. „Polacy o źródłach energii odnawialnej. Wyniki badania opinii publicznej. Wycinek z „Krajowego Planu Rozwoju Mikroinstalacji Odnawialnych Źródeł Energii do 2020 roku". Instytut Energetyki Odnawialnej, Związek Pracodawców Forum Energetyki Odnawialnej, Warsaw (2013) http://ieo.pl/pl/raporty/71-24/file $(15.12 .2015)$

5. Krajowy Plan Rozwoju Mikroinstalacji Odnawialnych Źródeł Energii do 2020 roku - Synteza, Instytut Energetyki Odnawialnej, (2013) http://demokracjaenergetyczna.pl/uploads/images/pdf/e kspertyzy Krajowy Plan Rozwoju Mikroinstalacji_O ZE.pdf(15.12.2015)

6. Wnioski z analiz prognostycznych na potrzeby Polityki energetycznej Polski do 2050 roku, Warszawa (2014) http://www.cire.pl/pliki/1/mg_pep_2050_wnioski_z_an aliz_prognostycznych_20140811.pdf (15.12.2015)

7. Ustawa z dnia 7 lipca 1994 Prawo Budowlane, (Dz.U. nr 89 poz. 414)

8. Ustawa $\mathrm{z}$ dnia 20 lutego 2015 r. o odnawialnych źródłach energii (Dz.U. poz.478) 